\title{
Municipal Solid Waste Source Identification, Characterization and Physical Composition Analysis, Case Study Wolkite Town, Ethiopia
}

\author{
Yenenesh Hailu*, Terefe Hanchiso, Abreham Bereta \\ Department of Natural Resources Management, Wolkite University, Wolkite, Ethiopia
}

Email address:

yenenesh2211@yahoo.com (Y. Hailu)

${ }^{*}$ Corresponding author

\section{To cite this article:}

Yenenesh Hailu, Terefe Hanchiso, Abreham Bereta. Municipal Solid Waste Source Identification, Characterization and Physical Composition Analysis, Case Study Wolkite Town, Ethiopia. American Journal of Environmental Protection. Vol. 8, No. 2, 2019, pp. 48-53.

doi: 10.11648/j.ajep.20190802.12

Received: April 14, 2019; Accepted: June 13, 2019; Published: July 15, 2019

\begin{abstract}
Solid waste, which is a consequence of day-to-day activity of human kind, needs to be managed properly. This study deals with municipal solid waste source identification, characterization and physical composition analysis the case of wolkite town, Ethiopia. inorder to conduct this study both primary and secondary data were collected and analyzed, subsequently the Findings of this study revealed that household, hotel, restorante, Kera, schools \& university, chat chewing residence are identified as major source of solid waste. Regarding solid waste physical composition and characterization analysis result indicated that in wolkite town the larger portion of solid waste generating is food and food related which constituted $25.86 \%$ followed by ash and fine sand which constituted $24.3 \%$, the third major kind of solid waste generated from the town at the household level is a mixture of different material named as other, then manure constituted $12.17 \%$, chat, leaves \&grasses, plastic, Festal, paper, textile, and glass \& ceramic constituted $5.7 \%, 5.7 \%, 4.2 \%, 3.42 \%, 1.9 \%$ and $0.39 \%$. Thus the finding of this study recommend to work on community awareness creation about proper solid waste management, and, it is very crucial to apply appropriate solid waste management system mechanism and establish small scale enterprise those will collect solid waste in the town.
\end{abstract}

Keywords: Solid Waste, Physical Composition, Characterization

\section{Introduction}

Having information about the sources and types of waste in an area is required in order to design and operate appropriate solid waste management systems [1].

Solid waste comprises different materials: like dust, food wastes, packaging in the form of paper, metal, plastic or glass, discarded clothing, garden wastes, pathological waste, hazardous waste and radioactive waste [2].

Solid waste can be effectively collected and properly disposed; it can also be converted to useful materials by separating it into its organic and inorganic constituents. Most solid wastes in developing countries have character fermentable nature. Since it composted of organic waste, it can be used as soil fertility improvement and minor plant nutrient [3].
Cities are generating an ever-increasing volume of waste, the effectiveness of their solid waste collection and disposal systems are declining. In urban centers throughout African regions, less than half of the solid waste produced is collected, and 95 percent of that amount is either indiscriminately thrown away at various dumping sites on the periphery of urban centers, or at a number of so-called temporary sites, generally urban waste management has been a challenge for municipalities and urban governments in the developing world, largely due to poor infrastructure, bureaucratic competence and limited institutional capacity of the municipalities [3].

Per capita amount of waste generated in Ethiopia ranged from 0.17 to $0.48 \mathrm{~kg} /$ person/day that is in urban areas and the amount of solid waste generated range from 0.11 to 0.35 $\mathrm{kg} /$ capita/day that is in rural areas. The range depends on 
several factors such as income and season. The total generation of municipal solid waste in Ethiopia in 2003 is estimated to be 2.8 to 8.8 million tones. This can be split to approximately 0.6 to 1.8 million tons from rural areas and 2.2 to 7 million tons from urban areas [4].

Rapid increase of the rate of municipal solid waste (MSW) production and disposal is a problem that is experienced by all counties in the world [4]. The generation and management of solid wastes are the problems facing both developing and developed countries. Generation of solid waste has become an increasing environmental and public health problem everywhere in the world [5].

City solid waste management has also a challenge for municipalities and urban governments in the developing countries. Inappropriate management of the solid waste that generated from the urban area of developing countries result in environmental pollution and also affecting the health of the people, this is because solid waste create favorable condition for the breeding of flies and rodents, so these insect are the primary carrier and dispersal agents of diseases in many developing countries in the world [6].

In many of the cities in Ethiopia the municipality administration is responsible for waste collection, despite the fact that, there is a wide variation in performance in relation to waste collection in cities of Ethiopia. It has become a common business practice to have household waste to be pre-collected by individuals who are organized through formal or informal association. The pre- collected waste is then transferred into containers then which are collected by municipalities. However, in many cities there are not enough containers to cover the population and for long periods of time vehicles are typically under maintenance or out of service. As there is very limited effort to recycle, reuse or recover the waste that is being generated [4].

Wolekite is one of the swiftly urbanizing centers, but has been tackled with an increasingly growing urban waste generation and management problem. There are many wastes that dispose from different source and the way of management of those solid wastes is poor, thus the objective of this research is to identify the source, analyzed physical composition and characteristics of solid waste in the study area.

\section{Material and Methods}

\subsection{Geographic Location}

Wolkite is found at the main road between Addis Ababa and Jimma at a distance of $135 \mathrm{kms}$ South- West of Addis Ababa. It belongs to the Southern Nations, Nationalities and people Region (SNNPR). Wolkite is the capital of Gurage zone and it also serves as a center for two rural administrative Woredas, namely Abeshige and Kebena woredas. The geographic location of the town is approximately $8^{\circ} 33^{\prime}$ Latitude and' $37^{\circ} 59^{\prime}$ 'longitude E. (Figure 1).

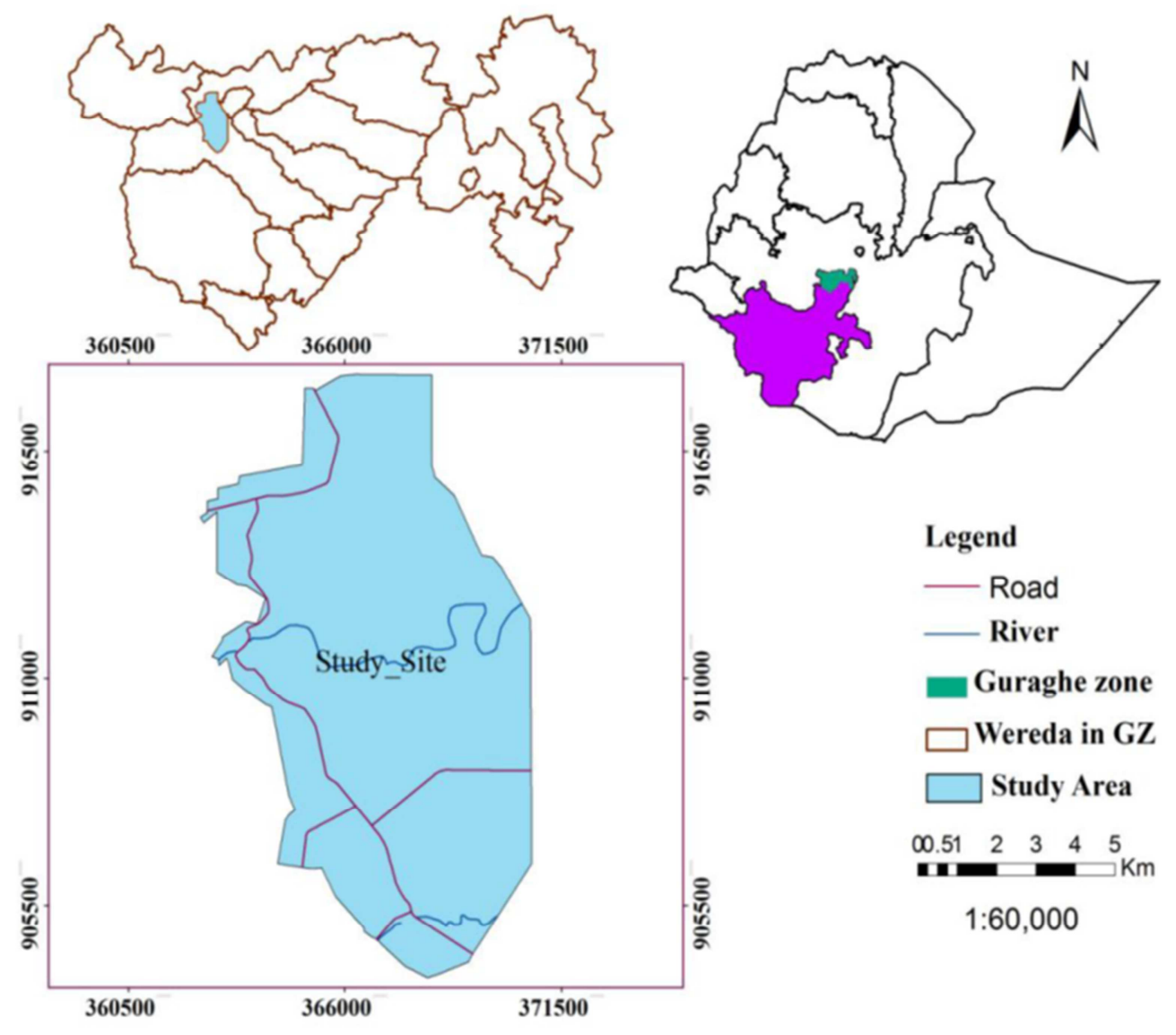

Figure 1. Map of wolkete town. 


\subsection{Methodology}

\subsubsection{Research Design}

This study aims at assessing the source identification, characterization/physical Compotation analysis, thus both qualitative and quantitative information are help to better understand, explain, and interpret the source, the type, amount of solid waste in the study area, Therefore this study was making use of Cross sectional research design, this is because the information were collected at one shot, which includes various quantitative and qualitative data sets. The qualitative approaches were comprised key informants interview and focus group discussion, whereas quantitative approach was conducted through household survey \& Solid waste characterization (physical component) analysis.

\subsubsection{Data Source and Type}

In order to conduct this study both primary and secondary was collected. The primary data was collected from sample households respondents, researchers' observation, and focus group discussion and key informants interview. Whereas Secondary data were collected thorough review of all available published and unpublished documents of relevant organizations were collected.

\subsubsection{Sampling Procedure and Sample Size Determination}

In order to select the sample household from Wolkite town this study were employ multi stage sampling technique, since wolkite town have three sub city i.e. Addise, Bekur and Gubre. In the first stage three kebeles were selected from each sub town purposively based on the availability of solid waste. In the second stage selected kebeles were stratified in to different Mender/ village accordingly those villages that are more relevant for this study were selected.

Accordingly from Selam Bere kebeles three villages were selected purposively these are 'Garaba', 'Atsede' and 'Mehal tena', from Bekure kebele 'katoleke','Hayat/Aresema' and Barunj and from Gubire' kebele megenanga' village were selected purposively, finally from the selected villages household respondent were selected using simple random sampling technique. To determine the total number of participant during household survey the study applies the formula that is provided by [7].

$$
\mathrm{n}=\frac{N Z^{2} P Q}{d^{2}(N-1)+Z^{2} P Q}
$$

Where;

$\mathrm{P}=$ Housing unit variable (Residential houses).

$\mathrm{Q}=1-\mathrm{P}$ (Non residential houses).

$\mathrm{N}=$ Total number of housing units 4809 [8].

$\mathrm{Z}=$ Standardized normal valued that corresponds to $95 \%$ confidence interval equal to1.96.

$\mathrm{d}=$ Allowable error $(5 \%)$.

Therefore, the result, $n=287$ of house household heads were selected from the selected kebeles.

In addition to selection of sample respondent from the three selected kebeles Hotels, restaurants, dinner and chat chewing residence were also selected purposively; subsequently they assessed and weight their daily solid waste generation rate.

\subsubsection{Data Collection}

Solid waste collection and sorting were conducted from Addis Hiwot, Selam Bere and Gubire kebeles. Gathering and sorting of solid wastes from the selected households were carry out for seven consecutive days, this is important in order to have an average result of the whole days of the week, in case of differences in waste generation between days, each household were give a plastic bag labeled with code.

Then after seven days collected solid waste from each sample household, were weigh and record.

Finally solid waste collected from different household were mixed together and characterize by different group/component like plastic, food, ash, glass and ceramics, metal, paper, textile and other.

\subsubsection{Data Analysis}

The solid waste components were determine after sorting sample solid waste in to different waste streams and weighted the sorted components separately. The collected solid wastes were dividing into different components. The weight percentages $(\%)$ of domestic solid waste components were determine for decomposable (food wastes, grasses and leaf), non-decomposable (plastic, paper, metal, glass, textile and Ashes and dust wastes.) The remaining waste consisting of hair, bones and small pieces of charcoal were categorized as 'other.

So in order to determine the physical character of the solid waste each material that collected as solid waste were weigh after the sorting. The percentage composition of each residential solid waste component generated from different source were determined by dividing the total amount of a particular solid waste type collected over a week, with the total amount of solid waste of all components within seven days and then multiplying it by 100 .

\section{Result and Discussion}

\subsection{Source of Solid Waste of Wolkite Town}

In developing solid waste management programs, it is important to identify the sources, and characteristics of solid waste. Municipal solid waste contains highly heterogeneous mass of discarded materials from urban residences, commercial establishments, institutions, street sweepings, and light industrial activities [9].

The information generated from focus group discussion participant and key informants interviewers elucidated that Wolkite town solid waste is generating from different source with different amount and kind. These are household, hotel, café \& restaurant, diner, chat chewing residence, beauty salon, public service provider (university, school, and health sector), zonal prison, municipal 'Kera, Commercial areas, Different fruit remnants from roadside markets and juice houses, Passengers generating wastes like tissue paper \& use and throw material. According to [10] municipal solid waste 
contains different composition which are also classifying them example plastic paper glass ceramic textile metal and inert waste.

Besides listing possible sources for solid waste, the FGD participant were also identified the major source of solid waste of the town, thus hotels, restaurants, household, chat chewing residence "Kera", and wolkite university are identified as one of the major source of solid waste. These are generally categories into residential, commercial area and institution area are the major source of solid waste and they are contributing a lot for waste increment in the study area solid waste amount. The above information is supported by [11] stated that there are five major sources of municipal solid waste of the town. These are residential areas, commercial areas, street sweeping, institutions, and small scale industries.

\subsection{Composition of Municipal Solid Waste}

Municipal solid wastes can be segmented into two major components called biodegradable and non-biodegradable. The biodegradable component of municipal solid waste constitutes organic wastes such as food waste, garden waste, and agricultural waste which undergo biological degradation under controlled conditions and can be turned into compost or organic fertilizer. While non-biodegradable wastes includes inorganic materials which can't be decomposed and degraded [12-13].

The composition of a municipal solid waste stream is important for designing material recovery facilities and developing other waste minimization programs and key determinate in decision concerning type of vehicles needed for collection and transfer, requirement for final disposal [14]. Successful characterization depends on obtaining representative samples of the collected solid waste and making statistically precise and accurate estimates of components [5], Thus for this study solid waste collected from different source, and making precise estimation of solid waste composition.

The type and component of solid waste is diverse with source, residential area, family size, economic statues and other factors, this idea is elucidated by the literature [1], accordingly the percentage of residence solid waste components vary with location, season, economic condition and many other factors.

Components that typically make up most municipal solid waste include food wastes, paper, ash, plastic, metals, textiles, glass and ceramics, etc. this study is also support this idea, the major component of solid waste are food, festal \& plastic, textile, ash \& fine sand, manure, piece of wood \& sugarcane byproduct, chat, leave $\&$ grass paper.

The physical composition by percent of residential solid wastes of wolkite town extracted from 287 sample households. The percentage composition of each residential solid waste component generated from households was determined by dividing the total amount of a particular solid waste component type collected over a weak with the total amount of solid waste of all components within seven days and then multiplying it by 100 .

According to the solid waste collected from Addise Hiwote kebeles specifically three village i.e. "Catholic", "Hayat" and "Timekete Bahire village" the major compositions of household solid wastes from the studied sample respondent and As presented from the following figure 2 food wastes and Ash\& fine sand constitute $25.53 \%$ of the total household wastes by weight manure constitute $22.7 \%, 19 \%$ constituted a mixture of sugarcane by product, \& piece of wood, $6 \%$ constituted festal and plastics bottles and the remaining $2 \%$ is constituted textile. studies conducted by [15] also showed that In Wolaita Sodo Town, from the total waste generation $(59.5 \%)$ were food, ash and dust $(25.08 \%)$, yard waste $(11.6 \%)$, plastics and rubber $(2.04 \%)$, paper and cardboard $(1.12 \%)$ and textile, wood, glass and metals accounted only $0.1 \%, 0.16 \%, 0.2 \%$ and $0.2 \%$ wastes, respectively.

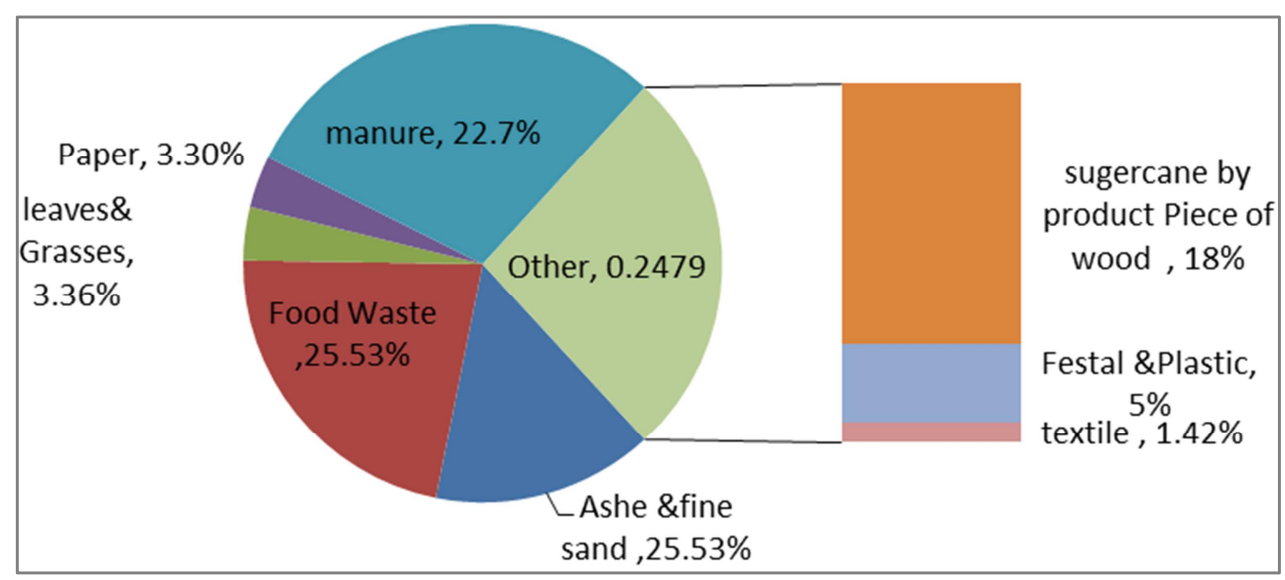

Figure 2. Solid waste composition at Addise Hiwot kebele.

Moreover the solid waste collected from Selam Bere kebeles were characterize, thus Figure 3 showed that the major compositions of household solid wastes from the studied sample respondent were food which constitute $28.1 \%$, Ash and fine sand constitute $24 \%$, festal constituted about $8.77 \%$, glass \& ceramics $0.88 \%$, chat, leaves and grasses constituted $8.77 \%$, paper constituted $3.51 \%$, textile constituted about $263 \%$, the remaining waste are the a mixture of different material which were difficult to separate and named as other. 


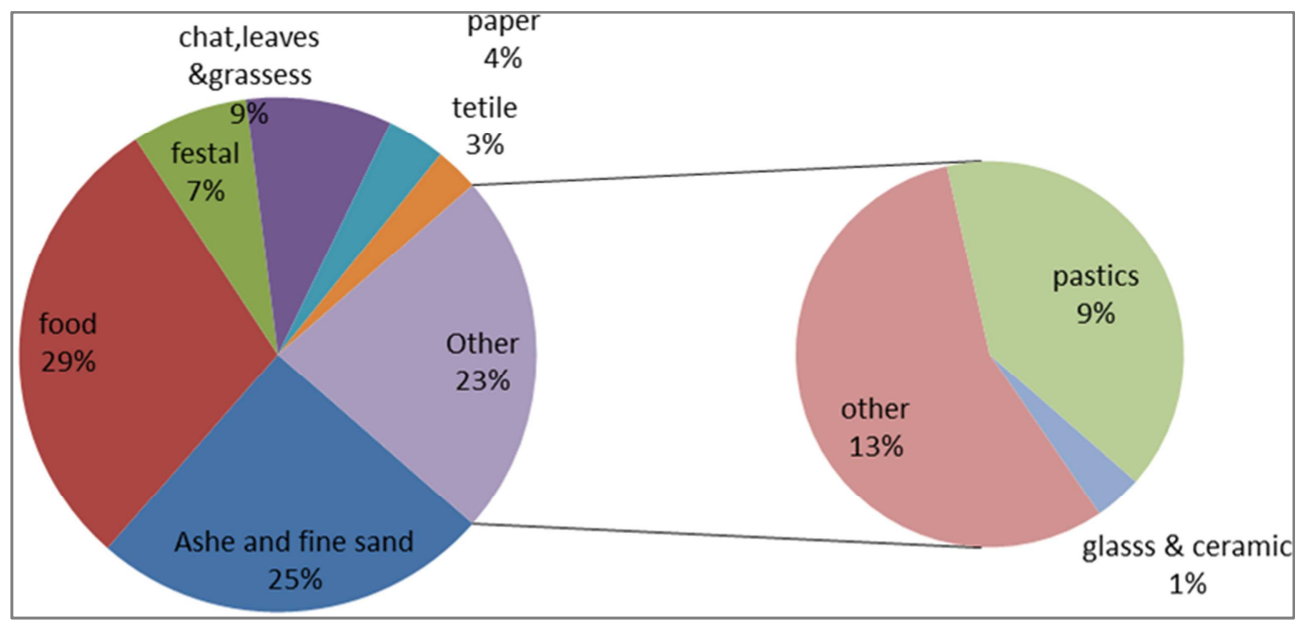

Figure 3. Solid waste compositions at Selam Bere kebele, wolkite town.

Generally information that generated from the collected solid waste at household level and the Figure 4 indicated that larger portion of the solid waste generated are food and food related which constituted $25.86 \%$ followed by ash and fine sand which constituted $24.8 \%$, the third major kind of solid waste generated from the town at the household level is a mixture of different material named as "other" which is $15.59 \%$, then manure constituted $12.17 \%$, chat, leaves \&grasses, plastic, Festal, paper, textile, and glass \& ceramic constituted $5.7 \%, 5.7 \%, 4.5 \%, 3.4 \%, 1.9 \%$ and $0.38 \%$ respectively. Whereas Studies conducted in Laga Tafo Laga Dadi town showed that, from the total waste generated in the city $48.66 \%$ plastic, $37.69 \%$ food and bone accounts for $37.69 \%$ which equal to food waste [16], means majority of waste categorized as non-biodegradable.

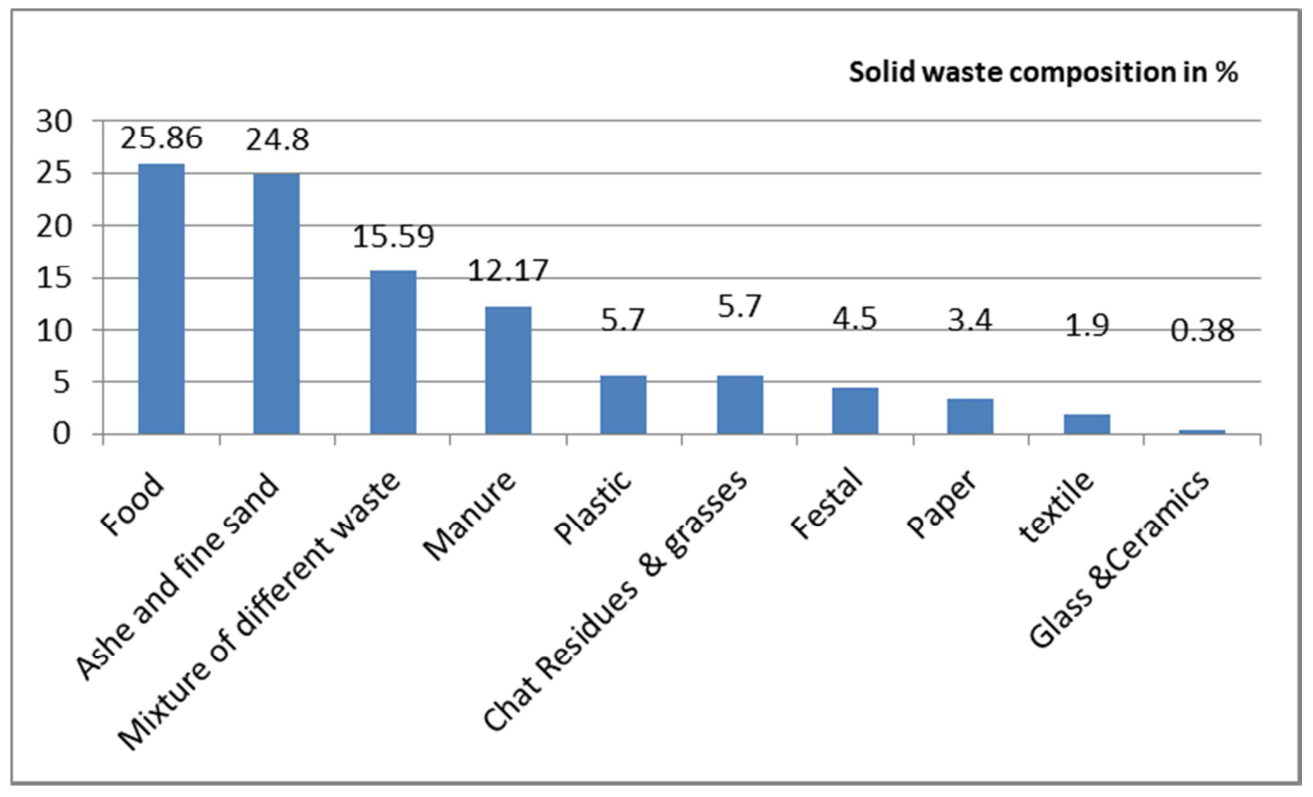

Figure 4. Solid waste compositions the town.

\section{Conclusions and Recommendation}

Solid waste is arising from our daily life and it generated at every stage of production and development process. Solid waste that generated from different source is effecting of the environment, health of human, animal and pollutes water bodies. Thus having information about the sources, composition and amount/ generation rate of solid waste is very crucial in order to design and operate appropriate solid waste management systems. This study was identify the source, and analyzed characteristic/composition of solid waste. consequently there are a number solid waste source those contribute for wolkite town and these source of solid waste generation rate and type of solid waste are varying depending on the source, according to solid waste physical compotation / characterization analysis result indicated that in wolkite town larger portion of the solid waste generated are food and food related which constituted $25.86 \%$ followed by ash and fine sand which constituted $24.3 \%$, the third major kind of solid waste generated from the town at the household level is a 
mixture of different material named as other", then manure constituted $12.17 \%$, chat, leaves \&grasses, plastic, Festal, paper, textile, and glass \& ceramic constituted 5.7\%, 5.7\%, $4.2 \%, 3.42 \%, 1.9 \%$ and $0.39 \%$ respectively.

Based on the finding of this research the Suggested future works include In order to manage solid wastes generated from different stakeholder, it is very crucial to apply appropriate solid waste management system.

Moreover Awareness creation to the communities and different institutions about the effects of inappropriate solid waste management system is necessary.

\section{References}

[1] Tchobanoglous G., Theisen H., and Eliassen R., (1977). Solid waste Engineering principles And Management Issues McGraw-Hill Kogakush, Tokyo.

[2] World Health Organization. (1984). Solid Waste Management in South- East Asia. WHO House, New Delhi, India. mohammed. G, 2015) acited as UNEP (1996).

[3] Oyelola, O and Babatunde, A, 2013), Characterization of domestic and market solid wastes at source in Lagos metropolis, Lagos, Nigeria.

[4] EPA (1995). Decision Maker's Guide to Solid Waste Management, Volume II.

[5] Zeng, Y., Trauth, K. M., Peyton, R. L. and Banerji, S. K. (2005). Estimation of Solid Waste Composition using two way stratification and optimum sample size: Theory and a case.

[6] USAID, 2009, Environmental Guidelines for Small-Scale Activities in Africa.
[7] Cochran, William G. Sampling techniques. John Wiley \& Sons, 2007.

[8] CSA (2007). Central Statistical Agency of Ethiopia Population and Housing Census Report.

[9] Dereje. (2001). Financial Urban Infrastructure and Services in Ethiopia. The Case of Solid Waste Management in Adama Town, Ethiopia.

[10] Baabereyir. (2009). Urban environment problem. case study of social and environmental Injustice in solid waste Management.

[11] Abebe Tegegne (2006). The Involvement of Micro and Small Enterprises in Solid Waste Management Services in Addis Ababa: The Case of Bole and Arada Sub-cities, Ethiopia.

[12] Solomon Cheru (2011). Solid Waste Management: A Case Study of Household Solid Waste Management in Arada Sub-City, Addis Ababa, Ethiopia.

[13] Yitayal Beyene. (2005). Domestic solid waste quantity and compositio nanalysis. Addis Ababa, Msc thesispaper, Addis.

[14] Corrales and Horton, N. (2004). Projection of population and housing census of Nshimi Irimana, J, 2004. Attitudes and Behavior of Low-Income Households towards the Management of Domestic Solid Waste in Tafelsing.

[15] Endrias G. (2017). Generation rate and physical composition of solid waste in Wolaita Sodo Town, southern Ethiopia. Ethiopian Journal of Environmental Studies and Management.

[16] Mesfin A. (2017). Solid Waste Generation Rate and Characterization Study for Laga Tafo Laga Dadi Town, Oromia, Ethiopia. Environmental Protection and Policy. 